\title{
Traduções de Charles Simic, Derek Walcott, Adam Zagajewski, Frank O'hara, Don Paterson, John Keats, Tamîm Ibn Muqbil
}

\author{
por Felipe Guarnieri
}

USP

fm.guarnieri@gmail.com

\section{De Charles Simic:}

\section{UMA CARTA}

Caros filósofos, pensar me entristece.

Convosco é o mesmo?

Justo quando quase penetro o númeno,

alguma antiga namorada vem me distrair.

"Ela nem vive mais!", urro aos céus.

A luz invernal fez-me tomar esta via.

Vi leitos cobertos com lençóis cinzas idênticos.

Vi homens mal-encarados agarrarem mulher nua, e banharem-na com água fria.

Davam para acalmar-lhe os nervos, ou era castigo?

Fui visitar meu amigo Jão, que me afirmou:

"Conquistamos o real ao superar a sedução das imagens."

Fiquei em êxtase, até eu perceber

que essa abstinência nunca me será possivel.

Peguei-me olhando pela janela.

O pai do Jão foi passear com o cachorro.

Ele dava passos dificeis; o cachorro o esperava.

Não havia mais ninguém no parque,

apenas árvores nuas de infinitos torsos trágicos

a dificultar o pensar. 
Dear philosophers, I get sad when I think.

Is it the same with you?

Just as I'm about to sink my teeth into the noumenon,

Some old girlfriend comes to distract me.

"She's not even alive!" I yell to the skies.

The wintry light made me go that way.

I saw beds covered with identical gray blankets.

I saw grim-looking men holding a naked woman

While they hosed her with cold water.

Was that to calm her nerves, or was it punishment?

I went to visit my friend Bob, who said to me:

"We reach the real by overcoming the seduction of images."

I was overjoyed, until I realized

Such abstinence will never be possible for me.

I caught myself looking out the window.

Bob's father was taking their dog for a walk.

He moved with pain; the dog waited for him.

There was no one else in the park,

Only bare trees with an infinity of tragic shapes

To make thinking difficult.

Charles Simic, em The Book of Gods and Devils (1990). In: SIMIC, Charles. New and Selected Poems, 1962-2012. New York: Houghton Mifflin Harcourt, 2013. 


\section{De Derek Walcott:}

31.

Meu clima agora é o charco, a plúmbea água prateada que secreta nos caniços ou rasteja numa monodia que se amortece alegre o impeto e a inveja e o desperdício de atos nobres em nome da reputação; meu frenesi é a estase, como um bote de casco bem firmado. Qual garça-real eu voo às plagas desoladas, ao naufrágio estriado que o musgo torna belo, onde a ave alça voo, em que se firma da proa em riste, onde os siris cravejam a perca, todo aquele vigor findo, com o qual eu busquei uma vida mais plena que essa busca pusilânime.

Penso num lugar especifico

que é Hunter's Cove: longe da estrada um sapo lança aos astros sua língua e transita; de um charco em fogo-fátuo ao avanço do crepúsculo e de um sapo o estrondo nos caniços de uma noite de vaga-lumes pontilhada e na água vacilante refletido um céu incerto.

$$
*
$$

My climate now is the marsh, the leaden silver water that secretes in reeds or moves with a monody that happily might deaden endeavour and envy and the waste of noble deeds 
for reputation's sake; my frenzy is in stasis, like a shallop with a staved-in hull.

Ifly like the slate-heron to desolate places, to the ribbed wreck that the moss makes beautiful, where the egret spread its wings lest it totter on the aimed prow where crabs scrape for a perch, all that vigour finished with which I sought a richer life than this half-hearted search.

I am thinking of a specific site which is Hunter's Cove: away from the road a frog shoots its tongue at the stars and traffic; of a marsh in marsh-light with charging dusk and the boom of a toad in the reeds of the firefly-flecked night and a heaven improbably swayed in mirroring water.

Derek Walcott, em White Egrets (2010). In: WALCOTT, Derek. White Egrets. London: Faber and faber, 2010.

\section{De Adam Zagajewski:}

\section{FILÓSOFOS}

Deixem de nos iludir filósofos

o trabalho não é uma dádiva o homem não é o objetivo maior

o trabalho é o suor mortal Senhor quando eu chegar em casa queria dormir mas dormir é apenas uma correia que me transporta ao dia seguinte e o sol é uma moeda falsa manhã rasgando minhas pálpebras seladas como antes nascer minhas mãos, terceirizadas e mesmo 
minhas lágrimas não me pertencem elas participam na vida pública

qual alto-falantes de lábios ressecados e um coração que brotou no cérebro

O trabalho não é uma dádiva mas dor incurável

como uma doença da consciência nua como novas moradias sociais

através dos quais vestindo coturnos de couro

passa o vento cidadão

$*$

Stop deceiving us philosophers

work is not a joy man is not the highest goal work is deadly sweat Lord when I get home I'd like to sleep but sleep's just a driving belt transporting me to the next day and the sun's a fake coin morning rips my eyelids sealed as before birth my hands are two Gastarbeiter and even my tears don't belong to me they participate in public life like speakers with chapped lips and a heart that's grown into the brain

Work is not a joy but incurable pain

like a disease of the open conscience like new housing projects

through which the citizen wind passes in his high leather boots.

Adam Zagajewski, em Selected poems(2004), trad. do inglês de Clare Cavanagh. In: ZAGAJEWSKI, Adam. Selected poems. London: Faber and faber, 2004. 


\section{De Frank O'Hara:}

\section{MEU CORAÇÃO}

Eu não vou chorar o tempo todo,

e nem vou rir o tempo todo, eu não prefiro um "tipo" a outro.

Eu teria a iminência de um filme ruim, não só daqueles que dão sono, mas daquelas superproduções espalhafatosas. Eu quero ser ao menos tão vivo quanto o vulgar. Ese algum aficionado por minha bagunça diz, "Nem parece o Frank! ", tão melhor! Eu não visto roupa cinza e marrom o tempo todo, não é? Não. Eu visto camisa social para a ópera quase sempre. Eu quero meus pés descalços, eu quero minha barba por fazer, e meu coraçãonão se pode planejar quanto a ele, mas sua melhor parte, a poesia, abre as alas.

$$
*
$$

I'm not going to cry all the time nor shall I laugh all the time, I don't prefer one "strain" to another. I'd have the immediacy of a bad movie, not just a sleeper, but also the big, overproduced first-run kind. I want to be 
at least as alive as the vulgar. And if

some aficionado of my mess says "That's

not like Frank!", all to the good! I

don't wear brown and gray suits all the time,

do I? No. I wear workshirts to the opera,

often. I want my feet to be bare,

I want my face to be shaven, and my heart-

you can't plan on the heart, but

the better part of it, my poetry, is open.

Frank O'Hara (1955), pub. na Paris Review 59 em 1970. In: O'HARA, Frank. The Collected Poems of Frank O'Hara, ed. Donald Allen. Berkeley: University of California Press, 1995.

\section{De Don Paterson:}

$O N D A$

Por meses eu vaguei por mar aberto como um timão sem direção nem freio e então matéria quase pura e abstrata com nada em mente além de uma alegria de quebrar-me: quão longe as águas rasas ouviam confissões minhas, num filtro eu dissolvia entre o cascalho limpo. Naquela vastidão nada era certo: mas eu senti meu ser drenar por água e quando vi por fim velas esparsas, docas em cores, cheias de garotos, do seu vestido azul eu desdobrei e me encontrei então a céu aberto. 
Tombei na praia. Varri o mundo todo.

$$
*
$$

For months I'd moved across the open water like a wheel under its skin, a frictionless and by then almost wholly abstract matter with nothing in my head beyond the bliss of my own breaking: how the long foreshore would hear my full confession, and I'd drain into the shale till I was filtered pure. There was no way to tell on that bare plain but I felt my power run down with the miles and by the time I saw the scattered sails, the painted front and children on the pier I was no more than a fold in her blue gown and knew I was already in the clear. I hit the beach and swept away the town.

Don Paterson, pub. na New Yorker em 03/03/2014.

\section{De John Keats:}

\section{TODOS ESSES SÃO VIS}

Os versos da Mansão do Luto do Sr. Scott, um sermão lá na Santa Madalena, o choro que esparrama de um conto açucarado, o gozo que segue a caminhada atrás dos bons amigos, chá ao lado de uma garota, um punhado infame 
de poemas (se dignos) com o autor por perto, um patrono bonacho, um porre de cerveja, a obra-mestra de Haydon, o café gelado de madrugada quando a Musa atiça os nervos, a voz de Coleridge, um lenço afrancesado sobre a poça a todo passo, batuque e fumo, um maldito vizinho grudado à sua flautatodos estes são vis. Porém mais vil é o soneto de Wordsworth sobre Dover. Dover! Quem poderia escrever aquilo?

The House of Mourningwritten by Mr. Scott, A sermon at the Magdalen, a tear Dropped on a greasy novel, want of cheer After a walk uphill to a friend's cot, Tea with a maiden lady, a cursed lot Of worthy poems with the author near, A patron lord, a drunkenness from beer, Haydon's great picture, a cold coffee pot At midnight when the Muse is ripe for labour, The voice of Mr. Coleridge, a French bonnet Before you in the pit, a pipe and tabour, A damned inseparable flute and neighbourAll these are vile, but viler Wordsworth's sonnet On Dover. Dover! - who could write upon it?

John Keats (1795-1821). In: KEATS, John. The complete poems, ed. John Barnard. London: Penguin Classics, 1977. 


\section{De Tamîm ibn Muqbil:}

1. Dois tempos marcam a eternidade: em um eu morro, em outro, eu me esforço para viver.

Os dois estão inscritos nas tábuas do meu destino.

A vida traz alegria e a morte traz repouso.

Quando eu deixar de existir, chora-me em meus méritos, E culpa a vida. Toda vida é uma tormenta.

2. Doce seria a vida se o homem fosse uma pedra

Fechada em si mesma à passagem dos eventos.

$$
*
$$

1. Deux temps marquent l'éternité: en l'un je meurs, En l'autre, j'oeuvre pour vivre.

Les deux sont inscrits dans les tablettes de mon destin.

La vie est heureuse et la mort reposant.

Lorsque je ne serais plus, pleure-moi selon mes mérites

Et blâme la vie. Toute vie est un tourment.

2. Douce serait la vie si l'homme était une pierre

Close sur elle-même au passahe des évenements.

Tamîm ibn Muqbil (fl. sec. VII), poema coletado em Le Dîwân de la poésie arabe classique (2008), trad. do francês de Adonis. In: ADONIS (ed.). Le Dîwân de la poésie arabe classique. Paris: Gallimard, 2008. 